\title{
The role of industry: An analytical framework to understand ICT transformation within the AEC industry
}

\author{
AUTHORS \\ Jacobsson, Mattias*o., Linderoth, Henrik C. ${ }^{\circ}$. and Rowlinson, Steve ${ }^{\bullet}$ \\ mattias.jacobsson@umu.se, henrik.linderoth@ju.se, hrecsmr@hku.hk \\ *Umeå University, Umeå School of Business and Economics, SE-901 87 Umeå, Sweden \\ ○Jönköping University, School of Engineering, P.O Box 1026, SE-551 11 Jönköping, Sweden \\ -University of Hong Kong, Dept. of Real Estate and Construction, Hong Kong, HK
}

\begin{abstract}
Despite wide-ranging research on information and communication technologies (ICT) in the Architecture, Engineering, and Construction (AEC) industry, little is known about the role that industry plays in the adoption and use of ICT. Based on observations of how the drivers for ICT use seem to be inconsistent with the industry's central characteristics, and drawing on Information Systems (IS) research that demonstrates the role of shared systems of meaning, the purpose here is to develop an analytical framework that explains how industry shapes the adoption and use of ICT. Building on a theoretically driven approach and a case study, a framework is first sketched and then substantiated through empirical illustrations. Three dimensions of industry are highlighted: the socio-cognitive environment, the market- and production environment, and institutional actors. It is explained how the interplay of these dimensions shapes the way the industry functions, which in turn influence the adoption and use of ICT. The outcomes of the interplay can either be aligned or misaligned with ICT, which explains why certain aligned applications are rapidly adopted, whereas other applications are not. The primary implication is that the framework can aid in analysing the need for structural adaptation when trying to achieve ICT-induced change.
\end{abstract}

Key words: Industry analysis, AEC industry, ICT, Transformation, Analytical framework

To cite this article: Jacobsson, M., Linderoth, H. C. J., \& Rowlinson, S. (2017). The role of industry: an analytical framework to understand ICT transformation within the AEC industry. Construction Management and Economics, Vol. 35, No. X, 1-16. DOI: 10.1080/01446193.2017.1315148

Acknowledgment: The authors of this paper would like to thank Jönköpings läns byggmästareförening for their financial support of this research. 


\section{INTRODUCTION}

Successful ICT transformation is paramount in almost all industries of today. Within the Architecture, Engineering, and Construction (AEC) industry however, such transformation has been slow in comparison to other industries (Love, Irani and Edwards, 2004; Ahuja, Yang and Shankar 2009). This situation has obviously been of concern for both researchers and practitioners since ICT transformation is a key source of increased efficiency, competitiveness, and innovation (Piccoli and Pigni, 2016).

Reflecting on this slowness and drawing on the understanding of ICT adoption and use that exists within the Information Systems (IS) field in general, along with research focusing on ICT transformation specifically, two observations can be made. First, one would assume that the features of the AEC industry would have attracted more attention in research that tries to explain the current situation, and secondly, one would also expect that the attempted transformation (in practice) would be more aligned with the central industry characteristics of the AEC industry.

In regard to the first observation, the role of industry, it is clear that AEC-oriented studies focusing on ICT transformation on an industry level are few (for exceptions see e.g. Croker and Rowlinson, 2007; Peansupap and Walker, 2005; Jacobsson and Linderoth 2010). In the more general IS research field, analyses of industry are also limited even if there exists a broad strand of studies showing how shared systems of meanings, and the influences of normative, cognitive, and regulatory dimensions, shape adoption and use of ICT at the organisational and inter-organisational levels (see. e.g. Orlikowski, 1992; Orlikowski and Gash, 1994; Griffith, 1999; Chiasson and Davidson, 2005).

In regard to the second observation, the industry characteristics and transformation, there seems to be some inconsistency within the AEC industry. On the one hand, it is well known that the central characteristics of the industry revolve around, for example, the type of collaboration upon which construction work is based, the centrality of communication to performance, and the importance of inter-organisational relations (see e.g. Harty, 2005). On the other hand, looking at research on ICT within the AEC industry, adoption and use seems to be propelled by an opposite reasoning, in terms of self-interest among actors and a focus on control and calculation (Davies and Harty, 2013; Jacobsson and Linderoth, 2010, 2012). Consequently, the current drivers for adoption and use seem to be inconsistent with some of the AEC industry's central characteristics. 
Based on this observed inconsistency, in combination with the general lack of focus on industry in research on ICT transformation within the AEC industry, the overall purpose of this paper is to develop an analytical framework that explains how industry shapes the adoption and use of ICT.

Beyond limited previous studies and observed inconsistency, arguments as to why industry is of relevance, and thus should be included in the analysis of ICT related activities exist from both a practical and a theoretical perspective. From a practical perceptive, rationale can be found for example in the uniqueness of the industry; the classification of industry made by government authorities; the wide array of industry-specific products and services promoted by information technology vendors like SAP, Oracle, and IBM (Chiasson and Davidson, 2005); common technology and marketing strategies within industries (Mauri and Michaels, 1998); as well as industry associations promoting the need for shared infrastructure and increased information exchange. From a more theoretical perspective, arguments can also be found in the fact that context or the environment at large, including for example institutional actors, production technologies, uncertainty and complexity, have previously been identified as central aspects to understand transformation, stability, inertia, or change (Scott et al., 2000; Melville et al., 2004).

In order to achieve the above-described purpose and understand the role of industry, two intertwined questions will be used to drive the examination. First, how can industry be analysed, and secondly, how does industry shape the adoption and use of ICT within the AEC industry? Guided by these two questions, and a two-step theoretically driven approach using a case study from a large Swedish contractor, a framework is sketched out and substantiated through empirical illustrations. Three important dimensions of industry are highlighted in the proposed framework. These are the socio-cognitive environment, marketand production environment, and institutional actors, where the 'socio-cognitive environment' refer to a broader belief system (in this case, within the AEC industry) that shapes the beliefs and ideas of individual actors (i.e. their interpretive frames) and thus influencing their actions. Through the empirical illustrations from the case study, the interplay among these three dimensions, and the way they influence the adoption and use of ICT are considered. It is shown how the outcomes of the interplay can be either aligned or misaligned with existing technology, which in turns explains why certain applications are rapidly adopted, whereas 
others are not. The primary implication is that the framework can aid in analysing ICT transformation and the need for structural changes when implementing ICT-induced changes.

The remainder of the paper is organised as follows: the first section provides a general discussion of how industry can be understood. This is followed by an assessment of industry and an outlining of a framework of how the AEC industry might influence the adoption and use of ICT. Thereafter, the method and the case are presented. Then there is an integrated analysis of the case in order to substantiate the proposed framework. The paper ends with a discussion and conclusions.

\section{UNDERSTANDING INDUSTRY}

If industry is an important element in understanding the adoption and use of ICT, then a core issue is to outline how industry can be understood and conceptualised. A wide array of different definitions of industry can be found depending on the perspective taken. Taking the perspective of production, Porter's (1980) basic definition is that industry is a group of companies producing products that are close substitutes for each other. The point of departure for this perspective is similar to that of an organisational population - that is, organisations facing similar environmental vulnerabilities foster similarities in adaptive capabilities and structural form (Hannan and Freeman, 1977). If other organisational populations and actors are included in the analysis, industry can be considered as an organisational field, which according to DiMaggio and Powell (1983:148) includes “... those organizations that in aggregate, constitute a recognized area of institutional life: key suppliers, resources and product customers, regulatory agencies and other organizations that produce similar services or products." Almost regardless of the perspective taken, it is important to understand that what is regarded as an industry is not static (Chiasson and Davidson, 2005). One contemporary example is the fluid boundaries between the telecom, computer, and entertainment industries.

When studying how industry shapes ICT related activities, Chiasson and Davidson (2005) argue that it is of crucial importance for future theorising that authors explain their view on industry. Following this recommendation, industry in this paper is primarily acknowledged as a dynamic organisational field in which there exists shared systems of meaning. 


\subsection{Dimensions of an industry framework}

Inspired by institutional theory, Chiasson and Davidson (2005) suggested that the role of industry in relation to ICT could be analysed and understood with regard to two main dimensions. These are: 1) the 'material-resource environment' that influences the production system, which transforms inputs to outputs, and 2) the 'institutional environment', which refers to the governance systems, organising principles, and the actors that create and enact the mentioned principles. In total, seven elements divided into two dimensions were proposed by the authors, as presented in table 1 .

\begin{tabular}{|c|c|c|c|}
\hline $\begin{array}{l}\text { Industry } \\
\text { dimensions }\end{array}$ & Elements & Characterized by & $\begin{array}{l}\text { Influence on ICT related } \\
\text { activities }\end{array}$ \\
\hline \multirow{4}{*}{$\begin{array}{l}\text { Material- } \\
\text { resource } \\
\text { environment }\end{array}$} & $\begin{array}{l}\text { Demand-side } \\
\text { factors }\end{array}$ & $\begin{array}{l}\text { Complexity, stability, or variation in } \\
\text { demand for product/services }\end{array}$ & (Not discussed) \\
\hline & $\begin{array}{l}\text { Supply-side } \\
\text { factors }\end{array}$ & $\begin{array}{l}\text { Scarcity, concentration of key inputs to } \\
\text { product/service }\end{array}$ & (Not discussed) \\
\hline & Technologies & $\begin{array}{l}\text { Material technologies, skills, and } \\
\text { knowledge used to transform inputs to } \\
\text { desired outputs }\end{array}$ & $\begin{array}{l}\text { Design and functionality of ICT } \\
\text { reflect most often an industry's } \\
\text { core technology }\end{array}$ \\
\hline & $\begin{array}{l}\text { Market } \\
\text { structure }\end{array}$ & $\begin{array}{l}\text { Alignment of suppliers, customers, } \\
\text { competitors that influence flow of } \\
\text { resources }\end{array}$ & $\begin{array}{l}\text { E.g. dominant suppliers or } \\
\text { customers drive industry } \\
\text { standards }\end{array}$ \\
\hline \multirow[t]{3}{*}{$\begin{array}{l}\text { Institutional } \\
\text { environment }\end{array}$} & $\begin{array}{l}\text { Institutional } \\
\text { logics }\end{array}$ & $\begin{array}{l}\text { Organizing principles, underlying } \\
\text { practices and belief systems }\end{array}$ & \multirow{2}{*}{$\begin{array}{l}\text { Institutional logics and actors are } \\
\text { encoded in data structures, } \\
\text { software and interfaces }\end{array}$} \\
\hline & $\begin{array}{l}\text { Institutional } \\
\text { actors }\end{array}$ & $\begin{array}{l}\text { Individuals and organizations that } \\
\text { create and enact institutional logics }\end{array}$ & \\
\hline & $\begin{array}{l}\text { Governance } \\
\text { systems }\end{array}$ & $\begin{array}{l}\text { Systems of regulatory and normative } \\
\text { control }\end{array}$ & $\begin{array}{l}\text { Managerial controls are reflected } \\
\text { in ICT features }\end{array}$ \\
\hline
\end{tabular}

Table 1. Features of industry and its influences on ICT related activities (based on Chiasson and Davidson 2005)

Table 1 is thus based on Chiasson and Davidson (2005) but slightly adjusted for reasons of presentation. Note, for example, that two of the elements are marked "not discussed" as they were not, in the original article, elaborated on in regard to how they influence ICT-related activities (see Chiasson and Davidson 2005).

The main advantage of taking the point of departure in Chiasson and Davidson (2005), which is the case in this paper, is that they both consider the nature of the material-resource environment (which in the introduction was shown to be quite unique in the AEC industry), and the shared systems of meaning or 'organising principles' of the industry (by Chiasson and Davidson also discussed as institutional logics). The nature of the material-resource environment reflects the uniqueness of the specific industry, and the 'organising principles' or logics represents the underlying belief systems and practices of actors that is shown to play a 
powerful role in shaping interpretations and legitimising actions (see e.g. Orlikowski and Gash 1994; Griffith, 1999; Chiasson and Davidson 2005). Scott (2001:41), who distinguishes among three pillars of institutions as carriers and enablers of the mentioned logics, argues that “... individuals do construct and continuously negotiate social reality in everyday life, but they do so within the context of wider, pre-existing cultural systems". Following this, institutions can be understood as social structures in terms of stable, valued, recurring patterns that have attained a high degree of resilience. Thornton and Ocasio (2008) further defines the notion of institutional logics as "the socially constructed, historical patterns of material practices, assumptions, values, beliefs, and rules by which individuals produce and reproduce their material subsistence, organise time and space, and provide meaning to their social reality" (Thornton and Ocasio 1999: 804). In essence, it can be argued that institutions thereby enable a social order (institutional logic) that it is simultaneously created by, and influences the actions of, a set of individuals within a given community/industry.

The main disadvantage with the Chiasson and Davidson (2005) framework is however that it does not provide any insight into whether, or how, an interplay among the proposed elements might shape how an industry functions. For example, it is not discussed whether technology might shape governance systems, or whether demand-side factors have the potential to shape technology (see e.g. Chenhall, 2003). By drawing on the conclusions by Porac et al. (1989), it can however be assumed that such an interplay exists. Also, the framework proposed by Chiasson and Davidson (2005) is industry unspecific, and thus in need of better detailing and adaptation. Thus, against this backdrop, the appropriateness and detailed content of the two dimensions needs to be scrutinised.

\subsection{A revised framework for analysing the AEC industry}

Following the identified downsides with the Chiasson and Davidson (2005) framework, it will in this section be suggested that the AEC industry can be better understood if the two dimensions (material-resource environment and institutional environment) are modified into three interrelated analytical dimensions, which will be called 'the socio-cognitive environment', the market- and production environment', and 'institutional actors'.

First, the material-resource environment dimension, as defined by Chiasson and Davidson (2005), is re-labelled as the 'market- and production environment'. Scott (2001) describes the material-resource environment as the factors that influence organisations as production systems transforming inputs to outputs. Thus, the production system cannot be regarded as 
de-coupled from the market but instead is tightly intertwined. Especially in the AEC industry, this is obvious when taking into consideration demands for the high degree of customisation that make projects the appropriate production technology. Secondly, it is possible to argue that governance systems are suitable to include as another element in this dimension. The reason for including governance systems in the market- and production environment is that both governance and control are crucial activities in a production system, and also central to the exchange with the market. In the AEC industry specifically, the triple constraint in project management (that is, time, cost, and quality) is an example of the interaction between a production system and the market. Thirdly, the product, it is argued, should be included as yet another element in the market- and production environment. Rationale for this can be found in Chatterjee et al. (2001) who argue that features of the product/service shape ICT-related activities. This argument is further strengthened on a more general level, as features of the product/service are known to shape the technology used. An example from the AEC industry is the immobility of the products (bridges, houses, etc.) and high degree of customisation, leading to the organising by projects (as the production technology). Hence, the nature of the product is of relevance to consider.

In the original framework by Chiasson and Davidson (2005), the institutional logic, as a part of the institutional environment, is described as the underlying organising principles that shape interpretations and guides actions. Having broken up the institutional environment, as proposed by Chiasson and Davidson (2005), and drawing inspiration from the IS field (see e.g. Orlikowski, 1992; Orlikowski and Gash, 1994; Griffith, 1999), the organising principles will be considered as a separate dimension called 'the socio-cognitive environment'.

The notion of a socio-cognitive environment has previously been shown to be important for the understanding of ICT-related activities on an organisational level (see e.g. Orlikowski, 1992; Orlikowski and Gash, 1994; Griffith, 1999), and it can thus be assumed to play an important role at an industry level as well. Arguments for using the socio-cognitive environment as a separate dimension can, for example, be found in Porac et al. (1989) who illustrated its importance with the way decision-makers construct interpretive frames, by which they interpret the competitive environment. These interpretive frames consist of beliefs about the identity of the firm, its competitors, suppliers and customers, and convictions about what it would take to compete successfully (Porac et al. 1989). Accordingly, the sociocognitive environment incorporates the general beliefs about important features of the 
industry, and it is shaped in the interplay with the organising of activities. Hence, it is here argued that it merits to be treated as a separate analytical dimension.

It should be noted here that the notion of a socio-cognitive environment has been around for a long time, and studied in various settings. Hence, to use it as a separate analytical dimension is not a new idea. Other concepts used to capture the socio-cognitive environment and the creation of interpretive frames include "cognitive maps" (Bougon et al. 1977), "frames" (Goffman 1974), and "interpretive schemes" (Giddens, 1984), to mention a few examples. Orlikowski and Gash (1994:176) explain: "a major premise of social cognitive research is that people act on the basis of their interpretations of the world, and in doing so enact particular social realities, and endow them with meaning." For the sake of clarity, a socio-cognitive environment is in this study defined as a broader belief system (in our case, within the AEC industry) that shapes the beliefs and ideas of individual actors (i.e. their interpretive frames) and thus influencing their actions.

With the socio-cognitive environment constituting a dimension of its own, only institutional actors are left in the institutional environment (as presented by Chiasson and Davidson, 2005). The institutional actors can be defined as the individuals and organisations that create and enact the socio-cognitive environment, and in turn shape the market- and production environment in this process. Consequently, institutional actors will be conceptualised as a separate dimension. It is, however, outside of the scope of this paper to conduct and in-depth analysis of how these actors re-shape the market- and production environment. It can however be argued (and will be shown) that it is the market- and production environment, along with the interaction among elements in that environment, that pave the way for an understanding of an industry's characteristics and how they shape ICT-related activities, especially if these features have remained stable for a period of time.

To summarise and provide an overview of the proposed modifications to the Chiasson and Davidson (2005) framework, a re-conceptualisation of the industry framework is presented in table 2. As can be noticed from the table, the new framework consists of three interrelated dimensions (and eight elements), which arguably are central in order to understand the AEC industry specifically. The proposed dimensions and their interrelatedness will be further discussed and substantiated through the case and the empirical illustrations. 


\begin{tabular}{|c|c|c|}
\hline $\begin{array}{l}\text { Industry } \\
\text { dimensions }\end{array}$ & Element(s) & Characterized by \\
\hline $\begin{array}{l}\text { Socio-cognitive } \\
\text { environment }\end{array}$ & Interpretive frames & $\begin{array}{l}\text { Definitions of organizational reality that serve as vehicles for } \\
\text { understanding and action, including assumptions, knowledge, } \\
\text { and expectations }\end{array}$ \\
\hline \multirow{6}{*}{$\begin{array}{l}\text { Market- and } \\
\text { production } \\
\text { environment }\end{array}$} & Demand-side factors & $\begin{array}{l}\text { Complexity, stability, or variation in demand for } \\
\text { product/services }\end{array}$ \\
\hline & Supply-side factors & Scarcity, concentration of key inputs to product/service \\
\hline & Technologies & $\begin{array}{l}\text { Material technologies, skills, and knowledge used to } \\
\text { transform inputs to desired outputs }\end{array}$ \\
\hline & Market structure & $\begin{array}{l}\text { Alignment of suppliers, customers, competitors that influence } \\
\text { flow of resources }\end{array}$ \\
\hline & Governance systems & Systems of regulatory control \\
\hline & Products & The nature of the product \\
\hline $\begin{array}{l}\text { Institutional } \\
\text { actors }\end{array}$ & Various industry actors & $\begin{array}{l}\text { Individuals and organizations that create and re-create the } \\
\text { socio-cognitive environment }\end{array}$ \\
\hline
\end{tabular}

Table 2. Industry influences: a revised framework

\section{CASE PRESENTATION AND METHODS}

Our interest in how industry shapes the adoption and use of ICT and by this how pervasive industry structures function as mental guidelines for social actions, follows a constructivist approach with an interpretivist epistemology. The notion of 'truth' and knowledge creation is thus dependent on social interaction, which both influences and guides our study design and method choices. Based on the purpose of developing an analytical framework that explains how industry shapes the adoption and use of ICT, a qualitative case study approach was adopted primarily based on its potential to obtain rich insights (Eisenhardt, 1989; Yin, 2013). Following the interpretivist epistemology, the largest part of the case study consisted of an ethnographically inspired study of a single partnering project in Sweden. As case study research is strengthened by the possibility of combining data (Eisenhardt, 1989; Yin, 2013), a variety of sources were used in the data collection, encompassing semi-structured interviews, observations, meeting participation, and documents. Rather than focusing merely on the project, the combination of data also allowed for: a) in-depth understanding of the building and construction company and its surrounding context in general; and b) what kind of ICT was selected and used in the particular company and why. The chosen methodology thus provides the opportunity to go beyond the studied company when claims are made. Coffey and Atkinson (1996:80) stress that "...the analysis of narratives can provide a critical way of examining not only key actors and events but also cultural conventions" which consequently means that narratives collected through semi-structured interviews are appropriate in order to understand contextual aspects of an industry and thus the nature of the socio-cognitive environment. 


\subsection{The company, the project, and its ICT-systems}

The company studied is a branch of one of the leading construction and property development groups in the Nordic region. In 2014, while the group had approximately 18000 employees and $€ 5,7$ billion in sales, in the same year the company had approximately 12000 employees, $€ 3,8$ billion in sales. The company builds everything from schools, hospitals, sports facilities and housing to roads, bridges, railways, and power plants. The studied project, worth approximately $€ 50$ million over a period of two years, involved the re-building and expansion of a public multi-activity arena. The existing building contained indoor swimming pools and an arena for indoor sports such as basketball and handball. The expanded arena contains an adventure pool, new swimming pool, a gym, and a bowling alley.

Within the company there were a total of approximately 60 different ICT systems with the number of users ranging from one to four thousand. The most important link between the permanent line organisation and the temporary organisation (i.e. the specific project) was the so-called operation system that consisted of five sub-systems: a customer relations management (CRM) system; two different systems for the planning of projects; a system for the calculation of project costs, containing standard costs and so called recipes; and an ecommerce system linked to major suppliers.

In the project, the most common ICT applications supporting information and communication flows were a database for sharing documents among contractor, sub-contractors and client; a digitised survey; an e-commerce system linked to major suppliers; and of course e-mail and mobile phones. Additionally, a 3D-based building and information model (BIM $\left.{ }^{\mathrm{I}}\right)$ was adopted half a year after the project started.

\subsection{Data collection process}

A total of 17 interviews were carried out with actors on different levels within both the permanent and the temporary (project) parts of the organisation. Interviewees were the chief executive officer of the company, the head of a regional unit, the head of a business district, site managers, ICT managers, project managers, and managers in a research and development department. All interviewees were selected based on their industry expertise and knowledge of the company and its processes. The interviews, that varied in length from one to two hours, were transcribed after completion. Additional empirical material was collected through

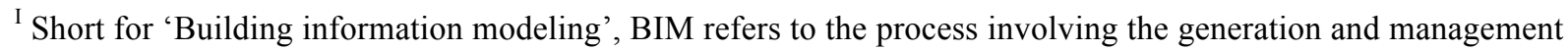
of digital representations of physical and functional characteristics of places.
} 
observations of 45 project-related meetings encompassing a total of 80 hours. The meetings were:

- production meetings at the main contractor's production site, involving the site manager, deputy site managers, foremen, and representatives of construction workers;

- project/design meetings with representatives of the main contractor, the subcontractors and their consultants, and the client representatives;

- meetings of the quality group with responsibility for internal quality audits;

- internal "check meetings" by the main contractor including the site manager, deputy site managers, purchaser, cost accountant, project manager, and planning manager.

Besides interviews and observations, additional empirical material was collected by shadowing a deputy site manager during one day at the construction site (Czarniawska, 2007), and from access to minutes from all internal meetings and the project's document database. When the case study was completed, an opportunity arose to collect additional data using group discussions with 25 site managers and supervisors from contractors of varying size. To facilitate the group discussions, the participants were divided into five smaller groups and given the task of discussing perceived problems in their daily practice. The duration of these discussions was half an hour and the results were later used to corroborate some of the findings from the case study. A summary of all collected material and its focus is provided in Table 3.

\begin{tabular}{|l|l|l|}
\hline Type of material & Scope & Focus \\
\hline Interviews & $\begin{array}{l}\text { Interviews with 17 respondents, } \\
\text { corresponding to approximately 25 } \\
\text { hours }\end{array}$ & $\begin{array}{l}\text { Understanding the structure of industry, } \\
\text { organization, and its processes }\end{array}$ \\
\hline Observations & $\begin{array}{l}45 \text { meetings encompassing a total of } \\
\text { approx. 80 hours }\end{array}$ & $\begin{array}{l}\text { Everyday practice reflecting ICT use and } \\
\text { cognitive frames }\end{array}$ \\
\hline Shadowing & 8 hours with a deputy site manager & Understand the everyday practice \\
\hline Document collection & Minutes from all internal meetings & Understanding focus in decision processes \\
\hline Group discussions & $\begin{array}{l}\text { 25 site managers and supervisors } \\
\text { (divided into 5 groups) }\end{array}$ & Perceived problems in daily activities \\
\hline
\end{tabular}

Table 3. Collected empirical material

\subsection{Analytical process}

To achieve the given purpose, a two-step theoretically driven approach was utilised. Each step relates to one part of the initially posed research question. Thus, the first step (relating to the question of how industry can be analysed?) constitutes a review and development of a framework that covers how the AEC might be understood. This first step is summarised in Table 2 in the background. The second step (relating to the question of how industry shape 
the adoption and use of ICT within the AEC industry?) takes its basis as the described case study and aims to further develop, substantiate, and illustrate how the proposed dimensions shape the adoption and use of ICT.

In the first step, there was a need to undertake a review of existing literature that conceptualised industry and its role in relation to ICT adoption and use. Acknowledging that reviews can be done in a vast number of different ways (Grant and Booth, 2009), a scoping approach was chosen as it has been shown to be useful when developing an integrated framework. The review involved three steps: 1) tracking the development of industry related studies; 2) reviewing previously presented ICT-industry frameworks; and 3) cross-examining those with specific characteristics that might be important in understanding industry (for summary, see Table 2).

In the second step, the case study focusing on ICT, the industry structure, the everyday practice, perceived problems, and decision process were analysed (see Table 3 for summary of empirical material). The goal was to examine and substantiate the previously proposed framework based on the empirical findings. When analysing the material, the framework developed in the first step (see Table 2) was thus used as the thematic backbone. Through an iterative process (Orton, 1997), the framework was cross-examined based on the case study material. The core focus (and main contribution of the study) was to understand the interrelatedness and dynamics of the framework. In doing so, observations and shadowing were particularly useful in understanding how the socio-cognitive environment reinforced actors' interpretive frames and influenced their actions.

\section{THE ROLE OF THE AEC INDUSTRY}

Based on the preciously sketched framework of industry (see Table 2), the following three sections will substantiate the framework with a focus on the interplay and how the dimensions (and elements) are manifested within the AEC industry. The first dimension analysed will be the socio-cognitive environment where it will be showed how a focus on time and actions is of central importance. In doing this, vignettes are used as illustrations to strengthen the arguments and substantiate the framework. The second dimension analysed is the market- and production environment. In this section, some underlying sources to the socio-cognitive environment and actors' interpretive frames are traced. Finally, the role of institutional actors will be analysed with regard to their re-shaping or reinforcing of the socio-cognitive environment and the market- and production environment. 


\subsection{The socio-cognitive environment}

When trying to understand the uniqueness of the socio-cognitive environment, the everpresent concern for time and action was soon observed among various actors. When asking a site manager what is the most important tool for governing projects he pointed towards the Gantt chart showing the planned progress of activities in the project. The reference to the Gantt chart came without any doubts or any acknowledgement that for example the budget might be of equal importance. The focus on time was a concern for both blue- and whitecollar workers, which led to a focus on action, as witnessed in the following vignette.

At a weekly Monday morning production meeting, a carpenter suddenly comes into the meeting room without knocking on the door. He is furious because there are no scissor lifts available and he demands the deputy site manager arrange for one immediately. The manager calls the local equipment rental firm. Approximately 45 minutes later a scissor lift is delivered. As they walk around the site together, the manager tells the observer that it is good that people are engaged in their work and always want the process to move forward. After having observed the delivery of the scissor lift they continue the walk to the floor below where the scissor lift was needed, and in a dark corner discover another scissor lift. The manager states that this is typical-people demand immediate action in order to solve a problem. In a resigned manner, he concludes that it would be better if the carpenters, instead of demanding immediate action, spent some extra minutes communicating with each other in order to find out if the missing equipment is available nearby.

It was later observed that such a focus on time and action was caused not only by actors within the project. A research- and development manager at the headquarters claimed that clients also expect immediate action, as described by the following story.

A contract manager gets a call from a client representative who explains that when he drove by the construction site the prior day, he did not see any excavators. The contract manager reacts to this by calling the site manager, asking why they have not yet started to excavate. The site manager, who is used to taking action, takes action for action's sake, by ordering an excavator to dig a hole, even though the hole will not be correctly excavated.

Another manager considered the tendency to act without reflecting on why. He described a typical situation where a few construction workers and an excavator working together ran into a problem. Wanting an immediate solution, the workers and the manager involved tried to 
solve the problem straightaway. The manager telling the story further explained that on many occasions it would have been better to stop the activity and instead communicate the problem to other disciplines and actors involved in that stage of the project.

Even people not working on site, and without a direct background in construction, were well aware of the focus on time and action, and that this pressure also comes from external stakeholders. A chief financial officer explained: "Sometimes we say that what is important is to 'just put a worker's shed on the worksite, so it looks like we are doing something, ,

With time and action consequently being central characteristics of the socio-cognitive environment, and at the core of actors' interpretive frames, the question of how and why this is the case can be raised. To answer this question, the paper will turn to how the market- and production environment is configured and works.

\subsection{The market-and production environment}

In this section, the interactions among the elements in the market- and production environment, and the consequence/influence of these interactions will be analysed in depth. The relations in the interactions among these elements are shown in Figure 1 and the outcomes of the interactions, as well as the consequences for ICT-related activities, are summarised in Table 4.

Organising production activities by projects has previously been put forward as one dimension that explains the shaping of ICT deployment in building and construction companies (see e.g. Croker and Rowlinson, 2007). This 'technology' (i.e. method to produce) has also been one explanation for different problems in the industry regarding, for example, innovation and knowledge transfer (DeFilippi and Arthur 1998; Gann and Salter 2000). However, in the following section it will be shown that technology per se is not the cause of problems. Rather it is the interplay among demand-side factors, the product, technology, and governance systems, which shape a market structure promoting market based short-term relationships among actors (see Figure 1). 


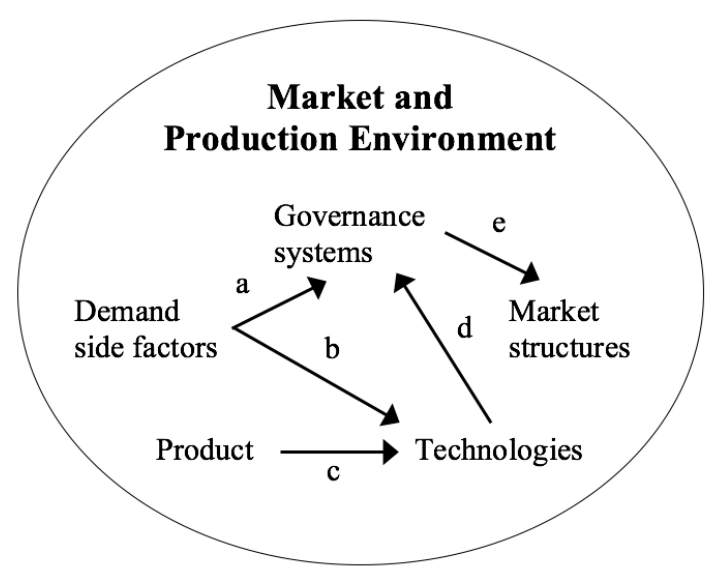

Figure 1. Interplay among elements in the market and production environment

A direct reason for the appropriateness of the technology in the AEC industry (i.e. organising production by projects) is the demand side factors (arrow b in Figure 1). No matter what the client wants to build, it is done through the project network due to the specialised nature of the products. A district manager said: "Even if a client has more or less unrealistic ideas and demands, there is always a builder crazy enough to accept a deal".

Moreover, it is doubtful whether clients (or architects) would accept a limited number of product models (which would be needed for another technology), as is the case in the automotive industry for example. A site manager said that "as soon as standardisation is mentioned, architects protest and draw parallels to infamous residential areas built in the 1960s and 1970s". Furthermore, organising by projects and the composition of the project team with occupational groups from a wide variety of firms can also be seen as a mode for dealing with a widely varying demand, and thus as a way of reducing risk. A business area manager stated that the industry is either in an economic boom, or in a recession, and equilibrium is never maintained. The upside of this technology is that risks for having excess capacity in an economic downturn are shared among companies in the project network. The downside is that the project is just a bracket in time with neither a history nor a future (see Kreiner, 1995; Björkegren, 1998; Hällgren, Jacobsson and Söderholm, 2012; Jacobsson, Burstöm and Wilson, 2013). This implies that projects do not have an organisational memory, nor a future allowing evolutionary processes where performance is improved.

Another reason for the appropriateness of the mentioned type of technology is the immobility of products (i.e. buildings and constructions) (arrow c in Figure 1). The production is almost always bound to a certain location. This implies that all resources needed for the production 
have to be allocated to a specific location during a certain period of time. When a project is finished, resources are reallocated to a new location. Thus, compared to other manufacturing industries, the AEC industry has a reverse relationship between the product and the "factory". In the AEC industry, the "factory" is mobile whereas the product is immobile. This product immobility could be another underlying reason for the way power is distributed. Thus, in addition to lack of complete specifications as well as management's unfamiliarity with local resources and environment, decision-making and financial control are delegated to the site level (see Dubois and Gadde, 2002), that is, to the site managers. Combined with the technology (organising by projects), such a delegation has implied a decrease in the power of larger firms, and a balancing of power among actors emerges especially when the work is underway (see also Earl, 1996). The reversed relationship between the product and the "factory", and the fact that projects function as separate entities decoupled from the firm was emphasised by a chief financial officer who stated: "We often act like hundreds of small companies."

The balancing of power among project actors also implies that smaller firms involved, such as architects or technical consultants, do not risk immediate reprimand if they do not deliver on time. In the case study, the architectural firm was late with the delivery of drawings due to its engagement in other projects, and even if it was obvious who was to blame, no measures were taken. This distribution of power combined with short-term relationships implies that even powerful actors have problems in putting demands on other actors to use certain ICTapplications (see Croker and Rowlinson, 2007).

The technology, shaped by demand side factors (such as customisation) and the immobility of the product, together with another demand-side factor, (namely the lowest price tender policy), has shaped the governance systems. (See arrows a and $d$ in Figure 1). This has resulted in a market structure characterised by market based short-term relations among actors (arrow e in Figure 1). On the demand side, historically there has been a strong reliance on competitive tendering that is supposed to promote efficiency (see Cox and Thompson, 1997), and clients have demanded a lowest price tender policy, making it a cornerstone in the governance systems. It can be claimed that all actors regard the lowest price tender policy as more or less institutionalised in the industry. When new contractual forms are introduced nowadays, the initiatives often come from larger construction firms. Still, several respondents confirm that it is clear that it is difficult to convince clients. In one interview, a higher-level manager in the company stated that they have had a hard time convincing clients about the 
benefits of so-called partnering contracts where the client and the contractors share "the pain and gain" (Jacobsson and Wilson, 2014). However, the lowest price tender policy has not by itself created the market structure. The combination of demand-side factors (the lowest price tender policy) and technology (organising by projects) has created a governance system that reinforces the market structure. Thus, organising by projects brings a governance system that in the interplay with the lowest price tender policy, has created the market structure. In project organising there are always trade-offs to be made among time, cost, and quality. As previously argued (see 4.1 socio-cognitive environment), time and action (essentially, the project's progress) is the most important components of the socio-cognitive environment influencing actors' interpretive frames, which accordingly can be seen as a consequence of the governance system.

In both the weekly production meetings and bi-weekly reconciliation meetings observed, the progress of project activities was the main topic discussed. Cost discussions most often related to material purchases or procurement of minor sub-contractors. Several experienced site managers interviewed stated that you get a sense of how the project is performing simply by walking around the site, and also monitoring the progress of the project activities. One of the site managers explicitly said: "When you get the financial reports, it's too late to do anything."

In order to promote the progress of the project and accomplish its objectives, incentives in the project organisation are time based. Site managers are for example evaluated on their ability to accomplish a project on time and budget, and among blue-collar workers, piece-rate wages predominate. The consequence is that all activities, not included in the piecework rate, or perceived to slow down the work, are regarded as threats. The missing scissor lift can be seen as one example of a perceived threat. Another example from the case is when the contractor and client wanted to focus on quality and reduce deviations by providing incentives like tickets and transportation to an ice-hockey game. A quality audit group was selected and in their meetings, members complained that it was very difficult to get site workers to report deviations and that the trade union was reluctant to accept the idea. The original idea was that site workers should report deviations by filling in a template. This however, was regarded as a task not included in normal duties (and a treat). The solution reached was that when site workers observed a deviation, they reported it to a manager and in doing so they were released from further responsibility. Piece-rate wages have also in previous research been regarded as a hindrance to renewal in the industry (see Håkansson and Ingemansson, 2013), 
although one site manager interviewed defended them. He argued that workers want to have a flow in the work process and piece-rate wages promote this flow. Theoretically, the quality of the product could be increased (and long-time costs be decreased) by increasing costs and time consumption during construction, at least as long as the client finds the increase in quality valuable. But such an arrangement is incompatible with the lowest price tender policy. If the lowest price tender policy is combined with the fact that the project is only a bracket in time with neither a history nor a future (see Kreiner, 1995; Björkegren, 1998), a governance system emerges that promotes a market structure where market-based interactions become the accepted way of doing things, and firms will pay little attention to relational elements in business transactions (see also Thompson et al., 1998). Thus, these circumstances have shaped existing work practices and the way of delivering projects, effectively preventing formal long-term relations being built among actors in the project network. Since contractors, sub-contractors, consultants, and architects are often involved in several parallel independent projects, the focus is not on the joint effort in the project network but instead on their own firm's interests. This implies that firms in the industry try to coordinate their own resources among the projects they are involved in-which can be seen as an explanation for low adoption of ICT aimed at coordinating specific projects. Instead, ICT has mainly been used for the purposes of controlling and calculating (see Jacobsson and Linderoth, 2010), whilst specific actors have taken responsibility for coordination (Jacobsson, 2011). In general, ICT applications supporting collaboration and coordination among project actors have been adopted only relatively recently. In the project studied, a document management system was used for this purpose, but representatives of the contractor who managed the project had to constantly remind other project actors to use the system and adhere to the agreed practice. More advanced collaborative ICTs, such as BIM, have been a hot topic in the industry over the last two decades, but the analysis above provide one explanation for the slow adoption rate of such technologies. 


\begin{tabular}{|c|c|c|c|}
\hline Arrow & Influence of elements & Outcome & $\begin{array}{l}\text { Consequences for adoption and use } \\
\text { of ICT }\end{array}$ \\
\hline $\mathrm{a}$ & $\begin{array}{l}\text { Demand side factors } \rightarrow \\
\text { Governance systems } \\
\text { Clients demand for } \\
\text { lowest price tender } \\
\text { policy }\end{array}$ & $\begin{array}{l}\text { Creates demand among actors } \\
\text { to control the consumption of } \\
\text { their own resources in the } \\
\text { project. }\end{array}$ & $\begin{array}{l}\text { Promotes the adoption and use of ICT } \\
\text { that aids monitoring and control of a } \\
\text { firm's consumption of resources in a } \\
\text { project. }\end{array}$ \\
\hline $\mathrm{b}$ & $\begin{array}{l}\text { Demand side factors } \rightarrow \\
\text { Technologies } \\
\text { Clients demands for } \\
\text { customized buildings } \\
\text { and construction }\end{array}$ & $\begin{array}{l}\text { Organizing by projects: } 1 \text { ) ease } \\
\text { the management of clients' } \\
\text { demands for varying features } \\
\text { of the product, 2) spread the } \\
\text { risks of excess capacity among } \\
\text { actors when demand decreases. }\end{array}$ & $\begin{array}{l}\text { Even if components are standardized } \\
\text { and activities are not standardized, } \\
\text { management try to standardize } \\
\text { activities in the management process } \\
\text { of projects by prescribing activities to } \\
\text { perform and support with document } \\
\text { templates in ICT-systems. }\end{array}$ \\
\hline $\mathrm{c}$ & $\begin{array}{l}\text { Product } \rightarrow \\
\text { Technologies } \\
\text { Immobility of product }\end{array}$ & $\begin{array}{l}\text { Implies that organizing by } \\
\text { projects becomes the most } \\
\text { appropriate production } \\
\text { technology. All actors involved } \\
\text { in a project have to be } \\
\text { mobilized at a specific site } \\
\text { during a "bracket in time". } \\
\text { Causes a decentralization of } \\
\text { power in larger firms, and a } \\
\text { balancing of power among } \\
\text { project actors. }\end{array}$ & $\begin{array}{l}\text { Historically it has been troublesome } \\
\text { to provide sites with bandwidth. ICT } \\
\text { has reached the office of the site } \\
\text { manager. Immobility of product } \\
\text { implies mobility of actors, implying } \\
\text { that applications like mobile phones } \\
\text { and e-mail were rapidly adopted. } \\
\text { Unlike other industries, no actors } \\
\text { have had power enough to enforce } \\
\text { others to use certain ICT. }\end{array}$ \\
\hline $\mathrm{d}$ & $\begin{array}{l}\text { Technologies } \rightarrow \\
\text { Governance systems } \\
\text { Organizing operations } \\
\text { by projects }\end{array}$ & $\begin{array}{l}\text { Implies a focus on the balance } \\
\text { among time, cost and quality } \\
\text { as central components in } \\
\text { governance structures. } \\
\text { Theoretically quality can be } \\
\text { increased by increasing time } \\
\text { and cost as along as a client } \\
\text { perceives higher value vs. } \\
\text { increases in cost. }\end{array}$ & $\begin{array}{l}\text { Adoption and use of ICT in a project } \\
\text { organization requires that resources } \\
\text { are set aside for investments. If the } \\
\text { client does not demand certain ICT } \\
\text { applications, investments in ICT will } \\
\text { create avoidable harm for the project } \\
\text { actors' profits. }\end{array}$ \\
\hline $\mathrm{e}$ & $\begin{array}{l}\text { Governance systems } \rightarrow \\
\text { Market structure } \\
\text { Mutually reinforcing } \\
\text { governance structures }\end{array}$ & $\begin{array}{l}\text { Governance structures shaped } \\
\text { by technology (organizing by } \\
\text { projects) and demand side } \\
\text { factors (lowest tender policy) } \\
\text { have created market based } \\
\text { short-term relations among } \\
\text { actors in the industry. }\end{array}$ & $\begin{array}{l}\text { No one feels responsibility for long- } \\
\text { term investment in ICT facilitating } \\
\text { what is best for the project. In the } \\
\text { next project, there will be a new } \\
\text { constellation of actors with (maybe) } \\
\text { new versions of ICT applications. But } \\
\text { powerful actors, e.g. large building } \\
\text { and construction companies can in } \\
\text { projects under own management } \\
\text { demand use of certain ICT. }\end{array}$ \\
\hline
\end{tabular}

Table 4. Interplay among elements in the market and production environment

\subsection{The role of institutional actors}

When the market- and production environment is described and analysed, some important institutional actors such as clients, site managers, trades unions, and large contractors, could be identified. In the Swedish AEC industry, there are three dominating contractors and around the turn of the millennium one of them initiated the use of partnering contracts. Managers in that company stated that clients were, at the outset, rather suspicious towards this new type of 
collaboration. One higher-level manager also stated that the fact that partnering survived the financial crisis was perceived as evidence of the robustness of the contractual form. It can thus be claimed that the large contractor has, through the introduction of partnering, succeeded in having and influence on the socio-cognitive environment. That is, the configuration of the relationship between clients and the contractors was altered, and by that also the way actors think about collaboration, time and action.

Other important institutional actors are government, industry associations, trades unions, and site managers. As an example of their influence, the features of the end product have been an object of more or less detailed governmental directives for years in Sweden. Recently, detailed directives about accessibility for disabled groups to public buildings have been developed, whereas directives for private houses have decreased somewhat. Other changes concern labour safety and energy consumption. Industry associations reinforce governance systems (of the market- and production environment) by providing templates for clients on their homepages for the most common contractual forms. Aside from labour safety issues, trades unions have been an important institutional actor in influencing governance systems by constantly promoting piece-rate wages. Some of the managers interviewed in the case study expressed dissatisfaction with the current design of the wage system because it, as they put it, "creates friction".

The position of site managers as important institutional actors can be explained by the fact that power is often delegated to the project organisation (i.e. the site managers), for example, due to the lack of complete specifications that imply a need for local adjustments (see also Dubois and Gadde, 2002). Incomplete specifications have become "the normal state" of the industry. Despite being the normal state, site managers in the focus group still perceived lack of complete specifications, or late arriving specifications, as a major inconvenience in their daily duties. Unreliable lead-times of suppliers and sub-contractors were also perceived to be a major source of the problem. It can thus be claimed that site managers have been forced to develop flexibility in managing projects in order to deal with uncertainties created by clients and suppliers. Consequently, both clients and suppliers can be seen as institutional actors that influence (or shape) the capabilities needed by site managers. Moreover, the capacity of site managers to manage uncertainties might have created an image of them as heroic problem solvers. A chief information officer confirmed this view by saying: “... we start with the heroes in the company - the site managers", when describing the initiation of an IT-related project. However, the role of site managers as problem solvers might be changing. In some of 
the interviews, more experienced site managers stated that they have less time "to build", since they have to spend more time on administrative tasks. This is a consequence of the larger construction firms' attempts to control projects and site managers by providing them with ICT systems that should standardise quality and cost control in projects.

One of the most important institutional actors is still the client who plays a central role in shaping governance systems: first, directly via the demands of the lowest price tender policy, and secondly, indirectly via demands for more or less unique product designs which reinforces organising by projects as the most appropriate technology. However, in other situations clients have not used their power. For example, even if clients are claimed to be the greatest beneficiary when for example BIM is implemented, they have until recently not used their power to demand its use in projects (see Olofsson et al., 2008). One reason for this is that also clients are influenced by the existing socio-cognitive environment, by which it is assumed that the lowest price tender policy provides efficiency to the project network (see also Cox and Thompson, 1997). This might explain why major construction firms promote a more integrated use of BIM in Sweden, whereas major clients until recently have been hesitant in demanding BIM.

Until recently none of the mentioned institutional actors have tried to exercise influence over ICT-related activities in the industry. ICT has instead been used with a focus on internal processes. However, a few years ago the company in the case study started to demand the use of $3 \mathrm{D}$ modelling in the detailed design stage in all projects under own management. Today this is a requirement in all projects if they are not considered to be too small. More generally, it is common that clients also start to demand 3D-based documentation. In countries like Finland, UK, Singapore, and Sweden large public clients have taken the lead. It is however not clear how these new demands will shape the future of the AEC industry.

Taken together, the interplay among the three industry dimensions - the market- and production environment, the socio-cognitive environment, and institutional actors-are summarised in Figure 2. 


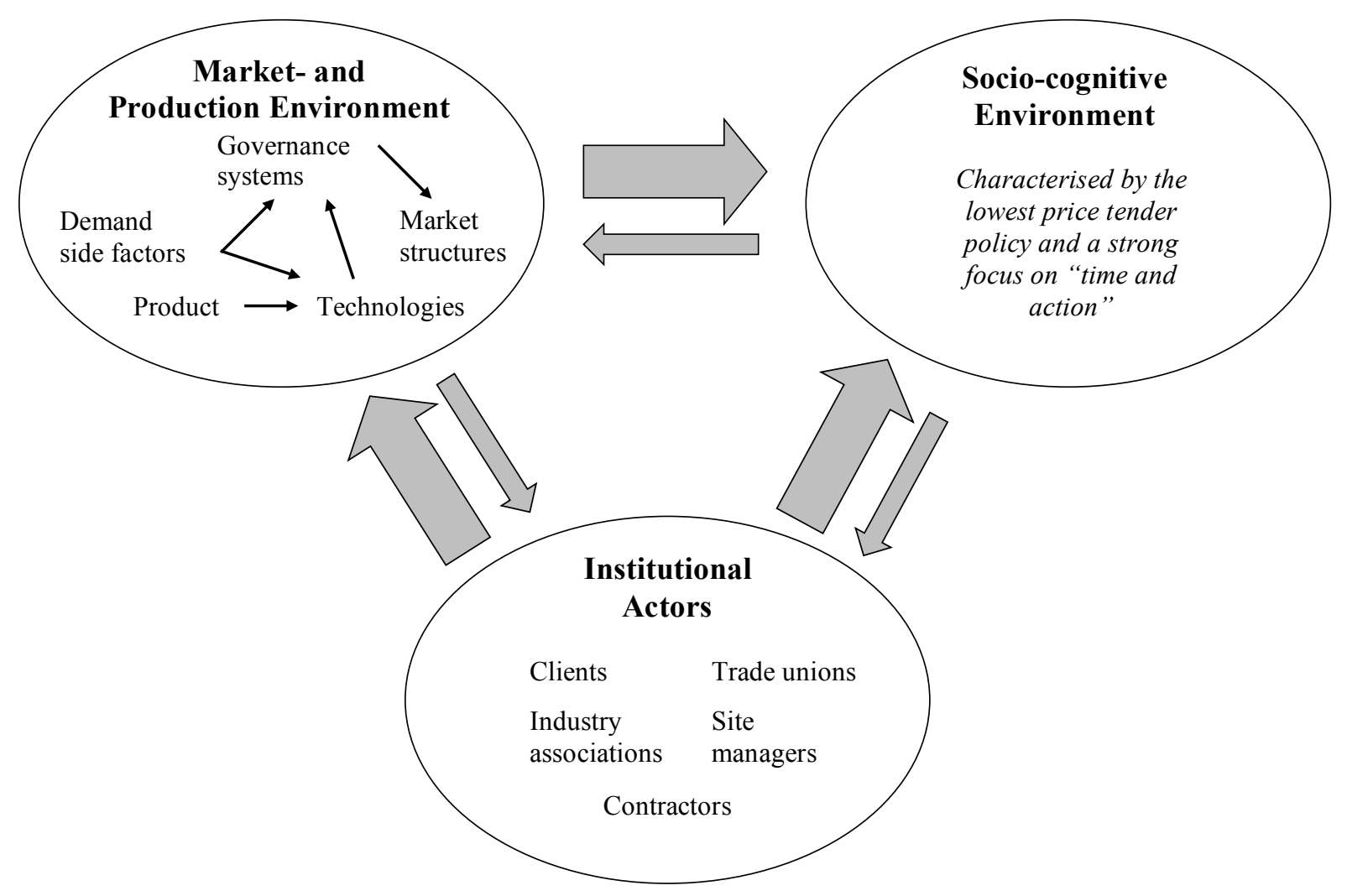

Figure 2. The interplay among industry dimensions

\section{DISCUSSION: THE INFLUENCE OF INDUSTRY ON ICT ADOPTION AND USE}

The general finding - as presented in the three previous sections, summarised in table 2illustrates the relationship among the three outlined dimensions; i.e. the socio-cognitive environment, the market- and production environment, and the institutional actors. Central to the relationship is that the interplay among the five elements in the market- and production environment, together with important institutional actors, mutually reinforces the sociocognitive environment, which characterised by the lowest price tender policy and a strong focus on "time and action". This confirms and substantiates the initially proposed framework of industry influences. More specifically related to the adoption and use of ICT, it has been observed that when actors give meaning and make sense of ICT applications, they draw on their interpretive frames and thus the characteristics of the socio-cognitive environment. This in turn shape ICT use in certain directions (see Figure 3) and implies that when ICT applications are interpreted in the socio-cognitive environment, some of their features align better than others with the way that the AEC industry currently functions - or is perceived to function. BIM as means for detecting clashes in field installations is an example of what actors perceive as a good alignment between the industry and ICT. Another example of a perceived 'good alignment' is systems facilitating the ability of higher-level managers to monitor and control the progress of projects. Influences in the opposite direction (from ICT to 
socio-cognitive environment) seem to be less common. That is, when the use of ICT is able to influence, or change, actors' interpretive frames (hence the dotted arrow in Figure 3).

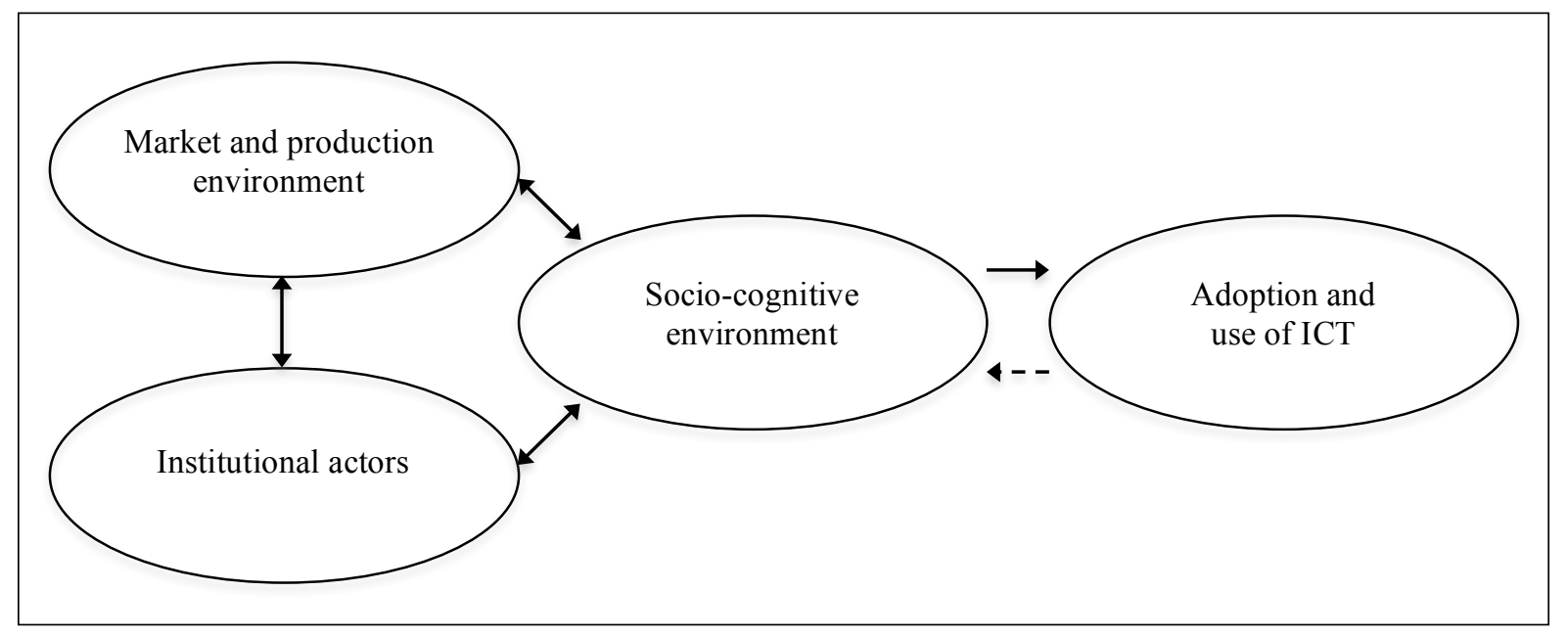

Figure 3. Industry characteristics interactions with adoption and use of ICT

To meet the overall purpose of this study, it was necessary to develop a framework for industry analysis. The framework should improve our understanding of ICT adoption and use, as well as help to detect the need for any changes as a result of implementing ICT.

By drawing on Chiasson and Davidson (2005), Porac et al. (1989) and Orlikowski and Gash (1994), among others, it has been possible to develop an AEC industry specific framework and to give a plausible answer to the question of why the industry looks and functions as it does. Characteristics of the AEC industry are for example that relations among actors are characterised by short-term market based interactions (Gann, 1996; Dubois and Gadde, 2002); driven by the lowest price tender policy; focused on action and short-term gains in operations (Jacobsson and Linderoth, 2010); resulting in actors optimising their own processes instead of the construction process as a whole (Love et al., 1998).

By starting the analysis with demand-side factors, demands for unique designs and an immobile product imply that organising by projects becomes the most appropriate technology. Even if the project is a temporary endeavour, this does not imply per se that relations among actors in a project network become short-term and market based. However, traditional demands from clients for a lowest price tender policy force actors to form a project network with those who happen to have the lowest bid. This can be seen as a major reason for the short-term market based relations characterising the industry. Thus, by further drawing on 
Porac et al. (1989), it can be claimed that actors' interpretive frames regarding what it takes to compete successfully in the industry are expressed by action orientation and a strive to accomplish the project on time and within budget, as defined by the lowest possible cost. These interpretive frames are shaped by the existing socio-cognitive environment. The focus on time and action has previously been recognised by Löfstedt and Räisänen (2014) who describe how a practical and problem solving orientation, or "doer mentality" is a strong source of identity construction on all managerial levels in construction firms. In this sense, the client can be regarded as one of the most powerful institutional actors. As long as clients prioritise a lowest price tender policy it will reinforce both governance systems and shortterm market based relations among actors, and also the existing socio-cognitive environment where time and action are key characteristics. Although competitive tendering is assumed to create efficiency (Cox and Thompson, 1997), innovation might be suffering. With constant short term focus, actors in the project network lack incentives to create innovations based on their relations because they do not know when they will co-operate the next time. Against this background, it is just a logical consequence that “... each discipline [actor] has become dedicated to the optimization of its own function, with little regard to, or understanding of, the construction process" (Love et al., 1998:381). Hence, mentioned consequences for ICT adoption and use.

However, clients, and especially public clients, have somewhat conflicting interests regarding what kind of contract might be appropriate. A higher-level manager within the contractor's organisation stated that public clients often have one function dedicated for the investment budget, and another function dedicated for operations and maintenance budget-where the latter is not always involved in the tendering process. Nevertheless, clients have often been regarded as an important source for renewal (potentially driving new ICT), whereas the role of suppliers has been marginal compared to other industries (Håkansson and Ingemansson, 2013). Also, in this research, supply-side factors were not seen to have a direct impact on the market- and production environment, and the creation of short-term market based relations. However, suppliers, including sub-contractors, can be claimed to have a direct impact on the socio-cognitive environment, where action is an important factor due to unreliable lead times. In this sense, the supply side amplifies the strength of the importance of actions in the shortterm. However, because of the way power is distributed within the AEC industry, large contractors have not taken advantage of their size to force suppliers to timely deliveries. 
The interplay among the elements in the market- and production environment thus shape the socio-cognitive environment where short-term objectives are in focus in order to save time and money in the project. The implications for ICT adoption and use are that project actors do not have any incentives for investing in ICT that should be used for supporting what is best for the project, unless short-term gains are obvious for an actor, or a special budget is set aside for investments (see also Croker and Rowlinson, 2007). Instead, ICT investments have been made in applications that can help the single firm to make its own work more efficient. For example, in this specific case, some subcontractors have for a long time used 3D-CAD for preparing drawings, but when drawings were delivered to the project, they were converted into 2D. At the same time, the advantages to the project of using BIM have been recognised for many years. Despite these advantages, it is only relatively recently that the adoption and deployment of BIM has gained momentum. Moreover, it is reasonable that the larger contractors have started to require that 3D based information models from different disciplines should be merged into one model. First, the gains from avoiding clashes in field installations in the production stages are obvious to them and secondly, larger contractors have resources to work with these development issues.

The adoption and use of ICT within in the AEC industry has increased rapidly during recent years. Most likely, this increase will continue and become even stronger when large public clients start to require BIM as part of project delivery. However, the question still remains as to whether increased use of BIM will lead to the type of transformation of the industry that advocators of BIM often claim (see e.g. Eastman et al., 2011). Research on enabling ICT has identified three categories of effects of ICT use - where it automates, informs, and transforms (Money et al., 1996). Automation effects refer to productivity improvements such as labour saving and cost reductions (see e.g. Zuboff, 1988). BIM use for clash detection or other simulations can be seen as an example of automation effects, especially where clash detection is aligned with requirements for short-term gains in the industry. Informational effects refer to ICT's capability to store, process and disseminate information, which in turn can improve decision-making, organisational efficiency, employee empowerment, use of resources, and quality (see e.g. Zuboff, 1988). Informational effects have appeared when contract managers and other higher level managers have been able to monitor and control the progress of single projects, but also by inscriptions in decision support systems in, for example, the project management process. Transformational effects refer to ICT's ability to facilitate and support process innovation and transformation, which is achieved by re-engineering processes and redesigning organisational structures (see e.g. Davenport, 2013; Venkatraman, 1994). BIM 
enables more integrated collaboration among actors, which would imply transformational effects. Sebastian (2011) claims that a more integrated collaboration would put architects, consulting firms, contractors, sub-contractors, and suppliers on the supply side in the building process making the client alone on the demand side, which in turn would be a very different situation that surely would affect the role of actors, responsibilities, tasks, and communication channels. In essence, it would change the current socio-cognitive environment.

Finally, the big issue in the near future concerns the question of what will happen when national initiatives are implemented where public clients require a BIM model as a part of project delivery. Will actors in the industry continue to be guided by their present interpretive frames where time and action are central elements? Or will some of the institutional actors have incentives and power to redefine the market- and production environment in a way that will change the socio-cognitive environment and thus the outlook on cooperation and long term gains for actors involved? The future will provide the answers.

\section{ConcLusions}

The main rationale for this research was the lack of previous AEC-oriented studies focusing on the role of industry in the analysis of ICT adoption and use. Based on observations of how the drivers for ICT use seem to be inconsistent with the industry's central characteristics, and drawing on IS research that demonstrates the role of shared systems of meaning (see. e.g. Orlikowski, 1992; Orlikowski and Gash, 1994; Griffith, 1999; Chiasson and Davidson, 2005), two intertwined questions were proposed. It was first asked how industry could be analysed, and thereafter, how industry might shape the adoption and use of ICT. The overall purpose was to develop an analytical framework that explains how industry shapes the adoption and use of ICT.

Based on the conceptual development and the case study illustrations, it can be concluded that the adoption and use of ICT is shaped by the interplay among three mutually reinforcing dimensions of the AEC industry. These dimensions are the socio-cognitive environment, the market- and production environment, and the institutional actors. The analysis, substantiated by empirical vignettes, illustrated how the interplay between the market- and production environment (shaped by interaction patterns among its elements), and institutional actors, give rise to a very distinctive socio-cognitive environment. The outcomes of this interplay can potentially be aligned with specific features of ICT, implying that certain applications will be more rapidly adopted, whereas other applications (that are not perceived to be aligned) will be 
rarely, if at all, adopted. The study thus contributes by extending previous IS studies that are focused on the role of industry in the deployment of ICT, by providing a dynamic analytical framework and illustrating its usefulness based on the AEC specific features as examples.

These findings have two important implications beyond the theoretical contribution of the framework for industry analysis and the potential for explaining why certain ICT applications will be successfully adopted and others not. First, by understanding the socio-cognitive environment and existing interpretive frames among actors, practitioners can, if they also have a general understanding of the application's specific features, gain an understanding of how well a specific ICT application is aligned within their own organisation. Secondly, from a more strategic perspective, by gaining an understanding of how the different elements shape the characteristics of the industry and the features of a technology, practitioners who want to promote an ICT-induced change can analyse the elements that need to be changed, or identify alliances that need to be built. For example, practitioners in the AEC industry who want to promote BIM as a means for cooperation among actors from the early stages of a project would realise that they have to start to build alliances with clients and persuade them to modify their governance systems to promote collaboration, since collaboration is essential to successful use of BIM. The framework will thus aid in the implementation of industryspecific ICT products and services.

Our above-mentioned contributions stretch in three theoretically different directions: first, they contribute to the construction literature that focuses on IS/ICT; secondly they contribute to more general IS literature; and thirdly they extend understanding of the AEC industry within the general literature of construction management.

Whilst previous research dealing with industry-specific characteristics and their role in ICT adoption and use has provided important understanding in terms of explaining the role of various knowledge domains (Söderholm, 2006), the mode of organising operations (Croker and Rowlinson, 2007), the focus on control and calculation (Jacobsson and Linderoth, 2010; 2012; Davies and Harty, 2013), and national organisational contexts (Gustavsson et al., 2012) to mention a few, this study extends previous knowledge through the development of a framework for industry analysis. More specifically, the paper contributes with illustrations and application of the framework to AEC industry-specific conditions. 
In regard to the contribution to more general IS literature, the proposed framework extends to previously presented, but not combined, dimensions of industry and its role in ICT adoption and use (see. e.g. Orlikowski, 1992; Orlikowski and Gash, 1994; Griffith, 1999; Chiasson and Davidson, 2005). Specifically, the contribution of alignment between industry and ICT applications has bearing beyond the AEC industry. Due to its aggregated nature, the framework has the potential for being transferred and adjusted to other industries and used for understanding deployment challenges. The framework thus has the potential to be used beyond the AEC industry and so the contributions are transferable.

Through the integration of industry specific features and the case study, an extended understanding of the AEC industry to the more general construction management literature is also provided. Although previous construction management research has shown in various ways how industry conditions (such as fragmentation, short-term orientation, and power distribution) impacts on the way the actors involved operate (see. e.g. Gann, 1996; Shirazi et al., 1996; Dubois and Gadde, 2002; Harty, 2005), the proposed framework provides additional clues to how these conditions influence each other. More specifically, it delves into how the Swedish AEC industry operates, and which industry dimensions might contribute to inertia in innovation and technological development beyond the adoption and use of ICT. 


\section{REFERENCES}

Ahuja, V., Yang, J., and Shankar, R. (2009) Study of ICT adoption for building project management in the Indian construction industry. Automation in Construction, 18(4), 415423.

Bartunek, J. and Moch, M. (1987) First order, second order, and third order change and organization development interventions: A cognitive approach. Journal of Applied Behavioral Science, 23(4), 483-500.

Björkegren, C. (1998) Learning from the next project, in Easterby - Smith, M., Arojou, L. and Burgoyne, J. (eds), Proceedings of the $3^{\text {rd }}$ Conference on Organizational Learning, Lancaster University, pp. 107-23.

Bougon, M., Weick, K., and Binrhorst, D. (1977) Cognition in organizations: An analysis of the Utrecht Jazz Orchestra. Administrative Science Quarterly, 22(4), 606-639.

Chatterjee, D., Richardson, V. J. and Zmud, R. W. (2001) Examining the shareholder wealth effects of announcements of newly created CIO positions. MIS Quarterly, 25(1), 43-70.

Chenhall (2003) Management control systems design within its organizational context: findings from contingency-based research and directions for the future. Accounting, Organizations and Society, 28(2), 127-168.

Chiasson, M., and Davidson, E. (2005) Taking industry seriously in IS research. MIS Quarterly, 29(1), 2-16.

Coffey, A. and Atkinson, P. (1996) Making sense of qualitative data, Sage, London.

Cox, A. and Thompson, I. (1997) Fit for purpose, contractual relations: determining a theoretical framework for construction projects, European Journal of Purchasing and Supply Chain Management. 3(3), 127-135.

Croker, N. and Rowlinson, S. (2007) The temporal nature of forces acting on innovative IT in major construction projects, Construction Management and Economics. 25(3), 227-238.

Czarniawska, B. (2007) Shadowing and other techniques for doing fieldwork in modern societies, Liber AB, Malmö.

Davenport, T. H. (2013) Process innovation: reengineering work through information technology. Harvard Business Press.

Davies, R. and Harty, C. (2013) Measurement and exploration of individual beliefs about the consequences of building information modelling use, Construction Management and Economics. 31(11), 1110-1127.

DeFillippi, R.J. and Arthur, M. (1998) Paradox in project-based enterprises: the case of filmmaking. California Management Review, 40(2), 125-140. 
DiMaggio, P. J. and Powell, W. W. (1983) The iron cage revisited: Institutional isomorphism and collective rationality in organizational fields. American sociological review, 48(2), 147-160.

DiMaggio, P. J., and Powell, W. W. (1991) The new institutionalism in organisational analysis. University of Chicago Press. Chicago, IL.

Dubois, A. and Gadde, L. E. (2002) The construction industry as loosely coupled system: implication for productivity and innovation. Construction Management and Economics. 20(7), 621-631.

Eadie, R., Browne, M., Odeyinka, H., McKeown, C., McNiff, S. (2013) BIM implementation throughout the UK construction project lifecycle: An analysis, Automation in Construction, 36 (December), 145-151.

Earl, P. (1996) Contracts, coordination, and the construction industry, in Management, marketing and the competitive process, Edward Elgar, P. Earl, Cheltenham.

Eastman, C., Teicholz, P., Sacks, R. and Liston, K. (2011) BIM Handbook: A Guide to Building Information Modeling for Owners, Managers, Designers, Engineers and Contractors, Wiley, Hoboken, NJ.

Eisenhardt, M. K. (1989) Building Theories from Case Study Research. The Academy of Management Review, 14(4) 532-550.

Gann, D. M. (1996) Construction as a manufacturing process? Similarities and differences between industrialized housing and car production in Japan. Construction Management and Economics, 14(5), 437-445.

Gann, D. M. and Salter, A. (2000) Innovation in project-based, service-enhanced firms: the construction of complex products and systems. Research Policy, 29(7/8), 955-972.

Giddens, A. (1984) The Constitution of Society: Outline of the Theory of Structure. University of California Press: Berkeley, CA.

Goffman, I. (1974) Frame Analysis, New York Harper \& Row.

Grant, M. J., and Booth, A. (2009) A typology of reviews: an analysis of 14 review types and associated methodologies. Health Information \& Libraries Journal, 26(2), 91-108.

Griffith, T. L. (1999) Technology features as triggers for sensemaking. Academy of Management Review, 24(3), 472-488.

Gustavsson, T. K., Samuelson, O., \& Wikforss, Ö. (2012) Organizing it in construction: present state and future challenges in Sweden. Journal of Information Technology in Construction (ITcon), 17, 520-534.

Hannan, M. T. and Freeman, J. (1977) The population ecology of organizations. American Journal of Sociology, 82(5), 929-964. 
Harty, C. (2005) Innovation in construction: a sociology of technology approach. Building research \& information, 33(6), 512-522.

Håkansson, H. and Ingemansson, M. (2013) Industrial renewal with the construction network. Construction Management and Economics, 31(1), 40-61.

Hällgren, M., Jacobsson, M., and Söderholm, A. (2012) Embracing the drifting environment: The legacy and impact of a Scandinavian project literature classic. International Journal of Managing projects in business, 5(4), 695-713.

Jacobsson, M. (2011) On the importance of liaisons for coordination of projects. International Journal of Managing Projects in Business, 4(1), 64-81.

Jacobsson, M., Burström, T., and Wilson, T. L. (2013) The role of transition in temporary organizations: linking the temporary to the permanent. International Journal of Managing Projects in Business, 6(3), 576-586.

Jacobsson, M. and Linderoth, H. C. J (2010) The Influence of Contextual Elements, Actors' Frames of Reference and Technology on the Adoption and Use of ICT in Construction Projects: a Swedish Case Study. Construction Management and Economics, 28(1), 13-23.

Jacobsson, M and Linderoth, H. C. J. (2012) User perceptions of ICT impacts in Swedish construction companies: 'it's fine, just as it is'. Construction Management and Economics, $30(5), 339-357$.

Jacobsson, M. and Wilson, T. L. (2014) Partnering hierarchy of needs. Management Decision, 52(10), 1907-1927.

Kreiner, K. (1995) In search of relevance: project management in drifting environments. Scandinavian Journal of Management, 11(4), 335-346.

Kerosuo, H., Miettinen, R. Mäki, T., Paavola, S., Korpela, J. and Rantala, T. (2012) Expanding uses of building information modeling in life-cycle construction projects. Work 41(1), 114-119.

Love, P. E., Irani, Z., and Edwards, D. J. (2004) Industry-centric benchmarking of information technology benefits, costs and risks for small-to-medium sized enterprises in construction. Automation in construction, 13(4), 507-524.

Love, P., Gunasekaran, A. and Li, H. (1998) Concurrent engineering: a strategy for procuring construction projects. International Journal of Project Management, 16(6), 375-383.

Löwstedt, M., and Räisänen, C. (2014) Social identity in construction: enactments and outcomes. Construction Management and Economics, 32(11), 1093-1105.

Löwstedt, M., and Räisänen, C. (2012) 'Playing back-spin balls': narrating organizational change in construction. Construction Management and Economics, 30(9), 795-806. 
Mauri, A. and Michaels, M. (1998) Firm and industry effect within strategic management: An empirical examination. Strategic management journal, 19(3), 211-219.

Melville, N., Kraemer, K. and Gurbaxani, V. (2004) Review: Information technology and organizational performance: An integrative model of IT business value. MIS Quarterly, (28(2), 283-322.

Money, J. G., Gurbaxani, V. and Kraemer, K. L. (1996) A Process Oriented Framework for Assessing the Business Value of Information Technology. The DATA BASE for Advances in Information Systems, 27(2), 68-81.

Monteiro, E. and Hanseth, O. (1995) Social shaping of information infrastructure: On being specific about technology. In Information technology and changes in organizational work, W. J. Orlikowski, G. Walsham, M. R. Jones, and J. I. DeGross (Eds.), London: Chapman and Hall, 325-343.

Olofsson, T., Lee, G., and Eastman, C. (2008) Editorial - Case studies of BIM in use, ITcon 13 (2008) 244-245, (http://www.itcon.org/2008/17 Retrieved Aug 3, 2016).

Orlikowski, W. J. and Gash, D. C. (1994) Technological frames: Making sense of information technology in organizations. ACM Transactions on information systems, (12:2), 174-207.

Orlikowski, W. (2007) Sociomaterial practices: Exploring technology at work. Organization Studies, 28(9), 135-1448.

Orlikowski, W. J. (1992) The duality of technology: Rethinking the concept of technology in organizations. Organization Science, 3(3), 398-427.

Orton, J. D. (1997) From inductive to iterative grounded theory: Zipping the gap between process theory and process data. Scandinavian Journal of Management, 13(4), 419-438.

Peansupap, V., and Walker, D. (2005) Exploratory factors influencing information and communication technology diffusion and adoption within Australian construction organizations: a micro analysis. Construction Innovation, 5(3), 135-157.

Piccoli, G., \& Pigni, F. (2016) Information Systems for Managers with Cases, Edition 3.1, Prospect Press: Burlington, VT.

Porac, J. F., Thomas, H. and Baden-Fuller, C. (1989) Competitive Groups as Cognitive Communities: The case of Scottish knitwear manufacturers. Journal of Management Studies, 26(4), 397-416.

Porter, M. (1980) Competitive strategy, The Free Press: New York.

Scott, W. R. (2001) Institutions and organizations, 2.nd ed., Sage Publications: Thousand Oaks, CA.

Scott, W. R. (2013) Institutions and organizations: Ideas, interests, and identities, 4.th ed., Sage Publications: Thousand Oaks, CA. 
Scott, W. R., Ruef, M., Mendel, P. and Caronna, C. (2000) Institutional change and healthcare organizations: From professional dominance to managed care, Chicago University Press, Chicago.

Sebastian, R. (2011) Changing roles of the clients, architects and contractors through BIM. Engineering, Construction and Architectural Management, 18(2), 176-187.

Shirazi, B., Langford, D. and Rowlinson, S. (1996) Organizational structures in the construction industry, Construction Management and Economics, 14(3), 199-212.

Stichcombe, A. (1959) Bureaucratic and craft administration of production. Administrative Science Quarterly, 4(2), 199-212.

Thompson, I., Cox, A. and Anderson, L. (1998) Contracting strategies for the project environment. European Journal of Purchasing and Supply Management, 4(1), 31-41.

Thornton, P. H., and Ocasio, W. (2008) Institutional logics. In The Sage handbook of organizational institutionalism, R. Greenwood, C. Oliver, R. Suddaby, \& K. SahlinAndersson (Eds.), London: Sage, 99-129.

Thornton, P. H., and Ocasio, W. (1999) Institutional Logics and the Historical Contingency of Power in Organizations: Executive Succession in the Higher Education Publishing Industry, 1958-1990. American Journal of Sociology, 105(3), 801-843.

Venkatraman, N. (1994) IT-Enabled Business Transformation: From Automation to Business Scope Redefinition. Sloan Management Review, 35(2), 73-87.

Yin, R. K. (2013) Case study research: Design and methods, CA: Sage publications.

Zuboff, S. (1988) In the age of the smart machine - The future of work and power. New York: Basic Books. 